\title{
ASSESSMENT OF ECONOMIC LOSSES ASSOCIATED WITH NITROGEN LEACHING IN AGRICULTURAL LAND IN LATVIA
}

Ieva SIKSNANE, Department of Environmental Engineering and Water Management, Faculty of Environment and Civil Engineering, Latvia University of Agriculture, Akademijas Str. 19, Jelgava, LV-3001, Latvia, ieva.siksnaane@gmail.com (corresponding author) Ainis LAGZDINS, Department of Environmental Engineering and Water Management, Faculty of Environment and Civil Engineering, Latvia University of Agriculture, Akademijas Str. 19, Jelgava, LV-3001, Latvia, ainis.lagzdins@llu.lv

Water is significantly important resource in everyday life. Parameters that characterize the quality of water resources are affected by human activities. In Latvia, water pollution with nutrients is often related to agricultural activities. As water circulation is sustained and uninterrupted process, nitrogen compounds are lost throughout the hydrographic network and transported both locally and internationally. Increased levels of nitrogen in the water lead to intensive eutrophication processes in the inland water bodies and the Baltic Sea, therefore, availability of clean water is decreasing. It is necessary to minimize and prevent water pollution as much as possible.

The aim of this research is to evaluate the economic losses caused by nitrogen leakage through agricultural drainage systems in Latvia. For this purpose, water protection regulations and agricultural runoff monitoring data are examined.

Evaluation process of the economic losses includes a comparison of the maximum extent permitted rates of nitrogen application with the theoretical optimum application rates and application rates determined at the research sites. For calculations ammonium nitrate was used as a type of fertilizer. From the results of this research it can be concluded that in about $41 \%$ the amount of nitrogen needed to reach the current yield level was exceeded. In addition, on average $13.2 \%$ and $15.4 \%$ of nitrogen applied annually as mineral fertilizers are lost through the subsurface drainage systems at the Berze and Mellupite research sites, respectively. This causes economic losses to farmers on average $61.13 \mathrm{EUR}_{\text {ha }}{ }^{-1}$ year $^{-1}$.

Keywords: agriculture, subsurface drainage, economic losses, leaching, nitrogen, phosphorus.

\section{INTRODUCTION}

The significant economic and environmental importance of water resources in human everyday life is listed and explained in many studies, including studies on the role of water in physiological processes and on water as an environment for species (Lichtenegger et al., 2011, Chaturvedi, 2011).

Previous research has shown that water resource quality and consumption is directly impacted by human activities. As a result of these activities, for example, discharge of polluting substances in water, level of contaminated water is rising and amount of clear and safe drinking water is decreasing.

In order to prevent and control the pollution of the water, with physical, chemical and biological substances, sustainable management of these resources is needed. The concept of above development is defined in the United Nations report, which states that it is a development that satisfies today's needs without endangering the needs of future generations.

Sustainable development is characterized by three aspects - environmental, economic and social. The introduction of such a development involves both the way of thinking and the creation and use of laws and other normative regulations both at the global and national levels.

Water resources are protected by legislation in national and global level. Regulatory documents of European Union and Latvian importance have been created to ensure good quality of surface and groundwater, promoting the sustainable use of water resources, as well as ensuring and improving the quality of water resources.

The most important normative documents at the European Union level are:

- Water Framework Directive (2000/60/EC), adopted by the European Union in 2000. The directive establishes measures for the protection of inland surface waters, transitional waters, coastal waters in order to prevent or reduce pollution, promote sustainable water use, protect the aquatic environment and improve the aquatic ecosystem.

- The Nitrates Directive (91/676/EEC), adopted by the European Union in 1991, which provides the protection of water against pollution caused by nitrates from agricultural sources polluting ground and surface waters.

Copyright (C) 2017 The Authors. Published by Aleksandras Stulginskis University. This is an open-access article distributed under the terms of the Creative Commons Attribution License (CC-BY 4.0), which permits unrestricted use, distribution, and reproduction in any medium, provided the original author and source are credited. 
In Latvia, the economic losses associated with nitrogen leaching previously have not been studied. The studies around the world tend to evaluate the environmental not economic losses. For example, researchers in China created an integrated model for assessment of fertilizer management and quantitatively rank the potential risk to the environment effectively. Also, researchers in the U.S. concluded that the use of cover crops potentially reduces N leaching (Lei et al., 2010; Marchi et al., 2016).

Water circulation in nature is global and unified, it takes place in continuous interaction between water resources in the atmosphere and in the soil, therefore, the polluting activities, affecting territory of Latvia, influence the entire water system globally.

In order to assess the environmental and economic impacts of water pollution caused by agricultural activities, water quality monitoring sites, located in the Saldus (monitoring site Mellupite) and Dobele (monitoring site Berze) districts were selected.

The problem targeted in this research is related with potentially unbalanced use of mineral fertilizers in agricultural activities which may lead to water pollution with nitrogen compounds that could cause undesirable environmental degradation and economic losses to the owners of agricultural lands.

This research aims to evaluate the economic losses caused by nitrogen losses from agricultural subsurface drainage fields.

\section{MATERIALS AND METHODS}

This research was conducted based on the monitoring data obtained at two agricultural runoff monitoring sites Berze (56 $\left.42^{\prime} 11.62^{\prime \prime} \mathrm{N}, 2^{\circ} 22^{\prime} 46.68^{\prime \prime} \mathrm{E}\right)$ and Mellupite $\left(56^{\circ} 29^{\prime} 77.90^{\prime \prime} \mathrm{N}, 22^{\circ} 14^{\prime} 12.53^{\prime \prime} \mathrm{E}\right)$. The time frame of this research lasts from 1995 through 2013. Water quality monitoring at these sites consists of flow proportional water sampling and continuous discharge measurements at subsurface drainage field scale. Composite water samples accumulated through the time period of one month were removed from the study sites according to a predefined schedule and stored in a cooler at $4^{\circ} \mathrm{C}$ until could be analysed in a laboratory. During the time period of this research the Hydrochemistry Laboratory of Latvian Institute of Aquatic Ecology and the Laboratory of the Latvian Environment, Geology and Meteorology Centre were used for chemical analysis. Water samples collected were analysed for total nitrogen according to the Latvian Standard methods by using oxidative digestion with peroxodisulfate. The measurement structures at both sites were equipped with V-notch weirs and pressure transducers for continuous water level measurements. Hourly water level measurements and associated discharge calculations were used to obtain daily, monthly and annual runoff representing hydrologic characteristics at the studied catchment areas. Nutrient losses $\left(\mathrm{kg} \mathrm{ha}^{-1}\right)$ were calculated based on the runoff $(\mathrm{mm})$ and concentrations $\left(\mathrm{mg} \mathrm{L}^{-1}\right)$ of total nitrogen in the water samples collected.

Annual interviews with farmers were a source for the information on farming practices in subsurface drainage fields. Interviews provided with the information on crops, dates of planting/harvest, yield, and fertilizer application rate. According to theses interviews the Berze and Mellupite research sites can be described as intensive and moderate intensive agricultural production systems, respectively.

The Berze and Mellupite research sites are situated in the Lielupe and Venta river basin districts, respectively, according to the implementation of the Water Framework Directive. In addition, the Berze monitoring site is situated in the nitrate vulnerable zone, according to the criteria defined by the Nitrates Directive. The location of monitoring sites is shown in Figure 1.

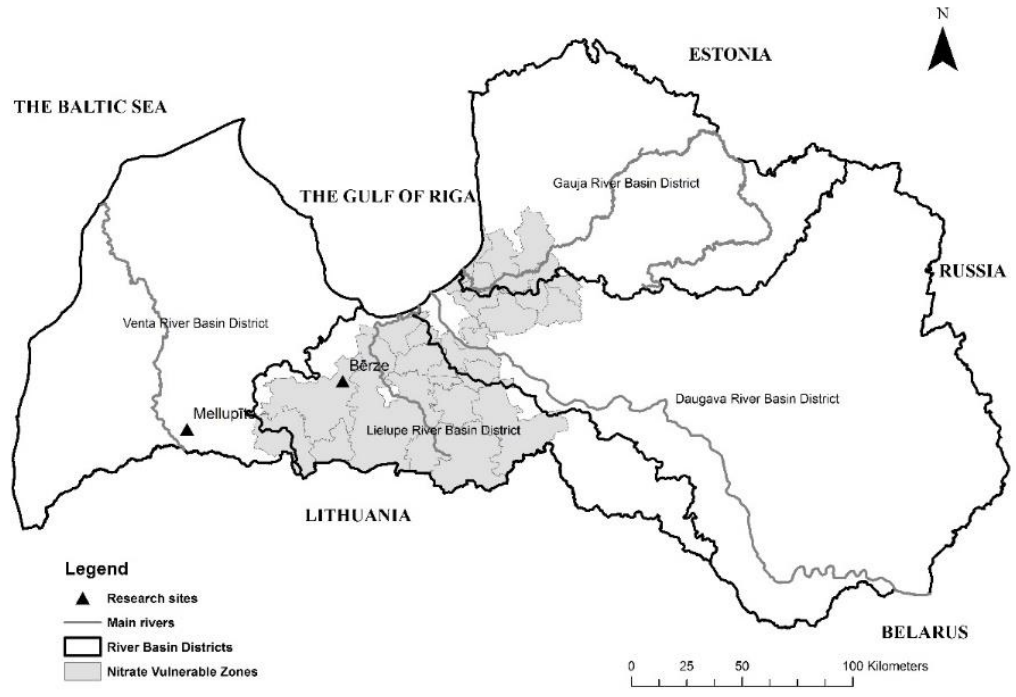

Figure 1. Location of the research sites

The share of arable land at the subsurface drainage fields at both research sites is $100 \%$, which allows to analyse the impacts from agricultural activities on drainage water quality. 
The price of nitrogen as mineral fertilization was obtained from local retailers.

\section{RESULTS AND DISCUSSION}

\section{Comparison of the maximum extent permitted rates of nitrogen application}

In order to obtain high productivity all, the necessary factors in optimal relationships should be ensured during the development phase of agricultural crops. German scientists came to the conclusion that plants are unable to absorb more nutrients as they optimally need and that excess substances that are not used by plants are released into soil, water and air (Lynch, Gabriel, 1985).

It can be concluded that unnecessary application of mineral fertilizers causes economic losses, does not increase yields, as well as cause environmental consequences as the excess nutrients in mineral fertilizers are lost from the soil.

In the calculation of the maximum allowable element content nitrogen has been studied in this research, while phosphorus application has not been studied, since Latvian legislation only regulates the use of nitrogen.

In order to evaluate the use of the nitrogen in the farms, it is necessary to compare the actual use with the maximum permitted nitrogen use in Latvia. The maximum amount of nitrogen in mineral fertilizers is specified in the Cabinet of Ministers Regulations No.834 "Regulations on the Protection of Water and Soil from Pollution Caused by Agricultural Activity by Nitrates". Analysing the results from the Mellupite monitoring site it can be concluded that nine times from the total of 32 crops during the study period or in $28 \%$ of the cases, the permitted limit values were exceeded. In two cases, values are twice above the limits, e.g., in 1999, the nitrogen content exceeded the permitted values 2.7 times, while in 2011 nitrogen application rate was about 2.3 times of the maximum permitted level.

In contrast, at the Berze monitoring site, it appears that 18 out of 35 values or about $50 \%$ the maximum permitted levels were exceeded. The highest values were observed in 1998 (exceeded by 1.9 times) and 2003 (exceeded by 2.3 times). It has to be mentioned that farmers are allowed to apply nitrogen as a mineral fertilizer based on the yield that are planned for a specific crop along with nitrogen removal for the relevant plant, content of organic substance in the soil, integrated after-harvest residues, as well as post-impact of previous crop etc. It is naturally that in some cases due to external factors such as duration of vegetation period, prolonged periods of excess moisture, frosts or other factors the planned yields cannot be obtained.

\section{Optimum application rates and application rates at the research sites}

The optimum amount of nutrients needed for agricultural crops is defined by its biological properties, but all growth and development requires nutrition. In the case where nutrient content in the soil is not sufficient to provide the necessary nutrition for the plant development, it is necessary to enrich the soil with these substances - fertilization. Sufficiently applied fertilizers provide multiple benefits such as increase in crop yield, products of high quality, high efficiency of fertilizer uptake, and improvement in soil fertility.

The optimum amount of nutrients needed for agricultural crops was calculated using the information collected by A. Kārklinš̌ and A. Ruža in 2013 "Field Crop Fertilizer Requirements", Part 2 "Nutrition of Plant Nutrients", using raw data: crop, yield ( $\mathrm{t} \mathrm{ha}^{-1}$ ), nitrogen and phosphorus in the soil (Kārkliņš, Ruža, 2013).

Analysing the results, it can be concluded that in 13 cases (about 41\%) the amount of nitrogen needed to reach the current yield level was exceeded. This excess amount is unnecessarily applied fertilizer; it can be prevented by calculating the optimal amount of nutrients each year before using fertilizer.

The monitoring data for both water quality monitoring sites is shown in Table 1 including sites crop grown in each year; yield of crops $\left(\mathrm{t} \mathrm{ha}^{-1}\right)$; the amount of fertilizers applied $\left(\mathrm{kg} \mathrm{ha}^{-1}\right)$; as well as total nitrogen losses through subsurface drainage systems $\left(\mathrm{kg} \mathrm{ha}^{-1}\right)$.

\section{Economic loss evaluation}

In this research the focus is on the nitrogen losses through subsurface drainage systems and amount of fertilizers applied on agricultural fields disregarding other factors that could serve as indicators for the calculation of economic losses. Pronounced socio-economic changes that took place over the time period of interest are the main reason why it is challenging to make more comprehensive economic analysis. In addition, there is a lack of initial data that could describe other costs involved such as costs of transportation, depreciation of transport, fuel costs, spread of fertilizers, crop type, etc.

As calculating the economic losses due to the loss of nitrogen in mineral fertilizers in the drainage water, the fertilizer type is used in calculations: Ammonium nitrate with an $\mathrm{N}$ - content of $34 \%$. Calculations were made using the percentage of $\mathrm{N}$ in ammonium nitrate fertilizer, as well as $\mathrm{N}$ load in $\mathrm{kg} \mathrm{ha}^{-1}$ in drainage runoff.

Evaluating the calculations performed on both farms, main conclusions were:

- The average losses per hectare were EUR 61.13;

- The average net nitrogen amount in water runoff was $18.90 \mathrm{~kg} \mathrm{ha}^{-1}$;

- The average nitrogen amount that drained from all used fertilizes was $14.3 \%$.

Table 1. Application of nitrogen fertilizers and losses of nitrogen in drainage runoff, 1995-2013

\begin{tabular}{|c|c|c|c|c|c|}
\hline \multirow{2}{*}{ Year } & Crop type & Yield, $\mathrm{t} \mathrm{ha}^{-1}$ & Fertilization rate, $\mathrm{kg} \mathrm{ha}^{-1}$ & \multicolumn{2}{|c|}{$\mathrm{TN}$ losses } \\
\cline { 4 - 5 } & $\mathrm{kg} \mathrm{ha}^{-1} \mathrm{year}^{-1}$ & $\%$ \\
\hline
\end{tabular}


Proceedings of the $8^{\text {th }}$ International Scientific Conference Rural Development 2017

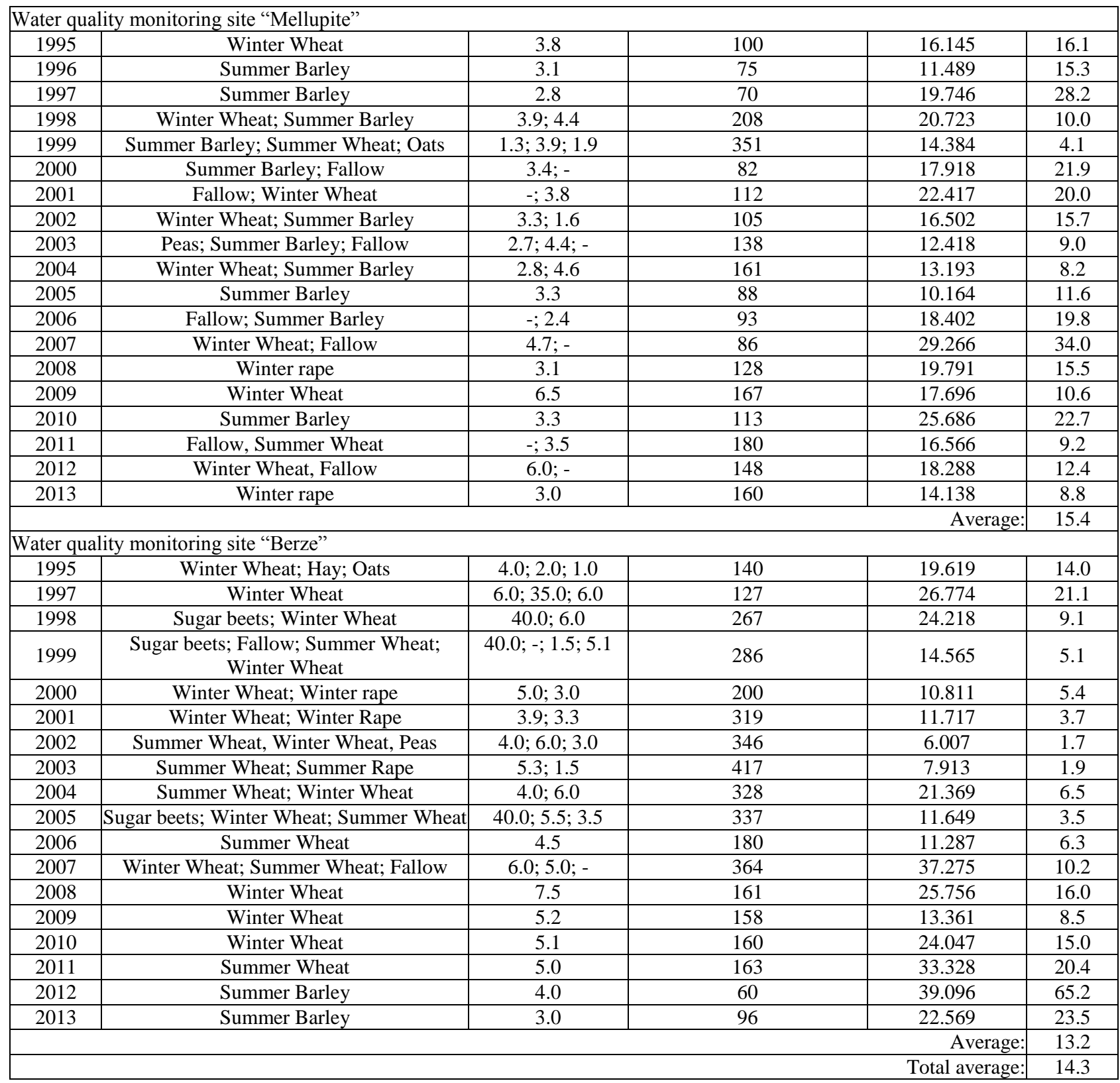

\section{Preventive measures}

In order to reduce the economic and environmental losses caused by nitrogen leakage eight effective measures have been selected as suitable to reduce nitrogen losses to adjacent water systems in agriculture, as well as to prevent leaching of nitrogen:

- Development of crop fertilization plan or determination of balance of plant nutrition elements;

- Land use change by turning arable land into a grassland;

- Intercultural cultivation;

- Winter crop farming;

- Implementation of controlled drainage;

- Implementation of organic farming practice;

- Buffer zone creation;

- Creation of artificial wetlands and phytoremediation.

The negative results from the release of nitrogen into the water are not quantifiable, but are visible due to the overgrowth of ditches, river systems and the Baltic Sea. Water systems are overgrown, eutrophication is taking place, bathing areas and water bodies are not available for recreation purposes; non-oxygenated zones in the water cause damage to fisheries, aquatic plants and animals, as well as to economies as a whole.

\section{CONCLUSIONS}


Water resources are important for both economic and environmental purposes. Traditionally the division of natural resources is based on the availability of these resources, as well as on the rate of life cycle of the substance, by dividing the two main groups - exhaustive and inexhaustible natural resources. Water is a relatively inexhaustible resource that is in constant circulation, but its distribution and availability is not even world-wide. The water cycle consists of precipitation, evaporation, condensation, accumulation and runoff. The runoff is a land-based waterway, which is very important because it provides energy and material exchange between land and the ocean, but it is endangered by various types of pollution, most of which are industrial and agricultural pollution.

Agricultural pollution by nitrogen leakage causes eutrophication. Eutrophication is the enrichment of water with nitrogen compounds, which results in accelerated algae growth and higher forms of plants, causing undesirable changes in the balance of aquatic organisms and the quality of the water concerned.

This study showed that during the research period of 1995-2013 on average $13-15 \%$ of nitrogen was lost when compared with the nitrogen applied at the monitoring sites. In the correlation analysis, it was proved that there is no correlation between the amount of fertilizer incorporated and the amount of nitrogen lost through the subsurface drainage systems. This means that there are other factors affecting nitrogen losses, which require different measures to be implemented.

The correlation analysis when the amount of fertilizers applied and harvested yields were analysed showed that there is a moderate, linear, positive correlation, which means that the increase of the fertilizer doses may increase the yield of crops, but it is necessary to optimize fertilizer application rate according to agronomic conditions.

Application of mineral fertilizers and leaching losses at the research sites caused an average loss of $61.13 \mathrm{EUR}^{-1}$ year $^{-1}$. The average net nitrogen amount in drainage runoff was $18.90 \mathrm{~kg} \mathrm{ha}^{-1}$, while average nitrogen loss was $14.3 \%$.

\section{REFERENCES}

1. Cabinet of Ministers Regulations No. 834 "Regulations on the Protection of Water and Soil from Pollution Caused by Agricultural Activity by Nitrates". 2015. Available at https://likumi.lv/doc.php?id=271376.

2. Chaturvedi, M.C. 2011. Development of Water for Life and Environment. University of Manitoba, Canada. 29 p. https://doi.org/10.1201/b11567-5

3. Kārklinšs, A., Ruža, A. 2013. Lauku kultūraugu mēslošanas normatīvi. LLU, Jelgava, Latvia. 52 lpp. [In Latvian]

4. Law on Pollution. 2001. Available at https://likumi.lv/doc.php?id=6075.

5. Lei, Y., Wang, Z., Zhang, S., Li, H. 2010. Assessment of potential risk of nitrate leaching on agriculture region using Arc-NLEAP model. Brisbane, Australia. 4 p.

6. Lichtenegger, W., Sehouli, J. 2011. Anatomy. Charite University Hospital Berlin, Germany. 7 p. https://doi.org/10.3109/9781841847658-5

7. Lynch, M., Gabriel, W. 1985. Environmental tolerance. Max Planck Institute for Limnology, Germany. 29 p.

8. Map of Latvia, Valsts Zemes Dienests. 2016. Available at http://www.balticmaps.eu/\#about.

9. Marchi, E.C.S., Zotarelli, L., Delgado, J.A., Rowland, D.L., Marchi, G. 2016. Use of the Nitrogen Index to assess nitrate leaching and water drainage from plastic-mulched horticultural cropping systems of Florida. International Soil and Water Conservation Research, Vol. 4, pp. 237-244. https://doi.org/10.1016/j.iswcr.2016.12.001

10. The Nitrates Directive, 91/676/EEC, 1991. Available at http://eur-lex.europa.eu/legal-content/EN/TXT/?uri=celex:31991L0676.

11. Water Framework Directive, 2000/60/EC, 2000. Available at http://rod.eionet.europa.eu/instruments/516.

12. Water Management Law. 2002. Available at https://likumi.lv/doc.php?id=66885. 